\title{
The structure of kaolinite and metakaolinite
}

\section{Gabriel Varga \\ Constantine the Philosopher University}

gvarga@ukf.sk

\author{
A kaolinit és a metakaolinit szerkezete \\ A tanulmány röviden ismerteti a kaolinit szerkeze- \\ tét és a metakaolinit kialakulására és szerkezetére
}

vonatkozó föbb elméleteket. A kaolinit szerkezete viszonylag jól ismert, de a kaolinitból $400{ }^{\circ} \mathrm{C}$ fölötti hömérsékleten kialakuló metakaolinité még nincs teljesen tisztázva.

\section{Introduction}

Building ceramics are gained by firing natural clays which contains various materials. The main and the most used mineral is kaolin. Kaolin is a soft, lightweight, often chalk-like sedimentary rock that has an earthy odor. Besides kaolinite, kaolin usually contains quartz and mica and also, less frequently, feldspar, illite, montmorillonite, ilmenite, anastase, haematite, bauxite, zircon, rutile, kyanite, silliminate, graphite, attapulgite, and halloysite. Kaolinite, the main constituent of kaolin, is formed by rock weathering. It is white, greyish-white, or slightly colored. Kaolinite is formed mainly by decomposition of feldspars (potassium feldspars), granite, and aluminium silicates. The process of kaolin formation is called kaolinization. Kaolinite is a hydrous aluminium silicate. It has a stable chemical structure and good physical properties for ceramic production. It is plastic, during drying phase the shrinkage is low, and its melting point is $1750^{\circ} \mathrm{C}$. After firing it has a white color $[1-5]$.

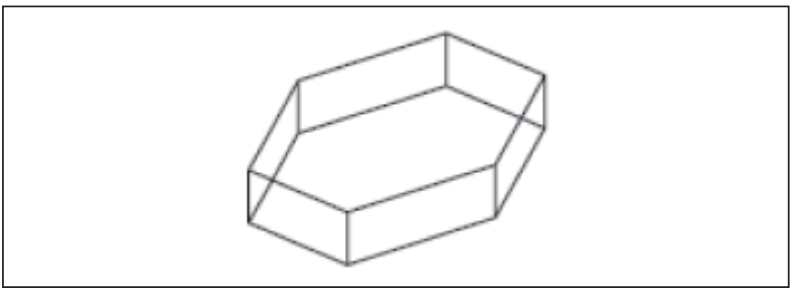

Fig. 1. - Base shape of the kaolinit crystal A kaolinit kristály kiindulási alakja

Kaolin or clays which contain kaolin are the base materials for ceramic industry, for pottery, and for building industry. Kaolinite is material for porcelain, electroporcelain, tile, brick, and chamotte production [1 - 4]. From these reasons, the kaolinite structure and its transformations during heating were studied intensively for many years. A short review of the kaolinite - metakaolinite transformation was published recently in the journal Építöanyag [6]. In this paper, the structures of kaolinite and metakaolinite are presented.

\section{Structure of kaolinite}

Kaolinite is the main constituent of kaolin. Its chemical structure is $\mathrm{Al}_{2} \mathrm{Si}_{2} \mathrm{O}_{5}(\mathrm{OH})_{4}(39,8 \%$ alumina, $46,3 \%$ silica, $13,9 \%$ water) which represents two-layer crystal (siliconoxygen tetrahedral layer joined to alumina octahedral layer exist alternately). The theoretical formula for kaolinite is $\mathrm{Si}_{2} \mathrm{Al}_{2} \mathrm{O}_{5}(\mathrm{OH})_{4}$ (other formulas are $\mathrm{Al}_{2} \mathrm{O}_{3} \cdot 2 \mathrm{SiO}_{2} \cdot 2 \mathrm{H}_{2} \mathrm{O}$ and $\mathrm{Al}_{2} \mathrm{O}_{7} \mathrm{Si}_{2} \cdot 2 \mathrm{H}_{2} \mathrm{O}$ ), which has a molecular weight of 258,071 $\mathrm{g} / \mathrm{mol}$. Kaolinite is build up from pseudohexagonal triclinic crystals with diameter $0,2-10 \mu \mathrm{m}$, with thickness $0,7 \mathrm{~nm}$ and its density is $2,6 \mathrm{~g} / \mathrm{cm}^{3}[5,7-9]$.

Kaolinite has a 1:1 sheet structure composed of $\mathrm{SiO}_{4}$ tetrahedral sheets and $\mathrm{Al}(\mathrm{O}, \mathrm{OH})_{6}$ octahedral sheets (or, expressed in other way, $\left[\mathrm{Si}_{2} \mathrm{O}_{5}\right]^{2}$ - sheet and $\left[\mathrm{Al}_{2}(\mathrm{OH})_{4}\right]^{2}$ sheet) with pseudo-hexagonal symmetry [10].The sheets are created from planes, which are occupied as follows: $\mathrm{O}_{6}-\mathrm{Si}_{4}-\mathrm{O}_{4}-(\mathrm{OH})_{2}-\mathrm{Al}_{4}-(\mathrm{OH})_{6}$. The morphology of the kaolin crystals is plate-like. The c-axis of the kaolinite crystal is perpendicular to the basal plane. A crystal system of the kaolinite is triclinic, the space group is $\mathrm{P} 1$, and lattice parameters are $\mathrm{a}=0,515 \mathrm{~nm}, \mathrm{~b}=0,895 \mathrm{~nm}, \mathrm{c}=0,740 \mathrm{~nm}$, $\alpha=91,68^{\circ}, \beta=104,87^{\circ}, \gamma=89,9^{\circ}$ [11]. An ideal cell of the kaolinite is electrically neutral. Its crystalochemical formula is $\mathrm{Al}_{4} \mathrm{Si}_{4} \mathrm{O}_{10}(\mathrm{OH})_{8}$ [8].

The first model of structure was designed by Brindley and Nakahira, see Fig. 2. and Fig. 3. The structure of the lattice layers is shown in Fig. 4. Because the layers are close one to other, the water molecules could not get between the sheets.

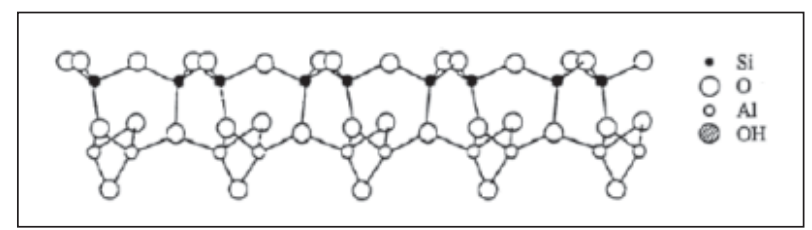

Fig. 2. - Structure of kaolinit designed by Brindley Nakahira, viewed from the a-axis direction

A kaolinit Brindley Nakahira által felvázolt szerkezete, az a tengely irányából nézve 


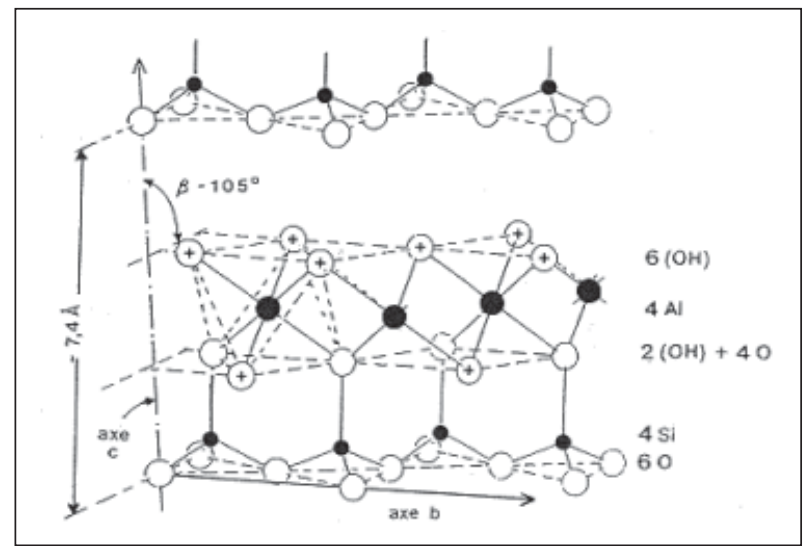

Fig. 3. - Chrystalochemical structure of kaolinit A kaolinit kristálykémiai szerkezete

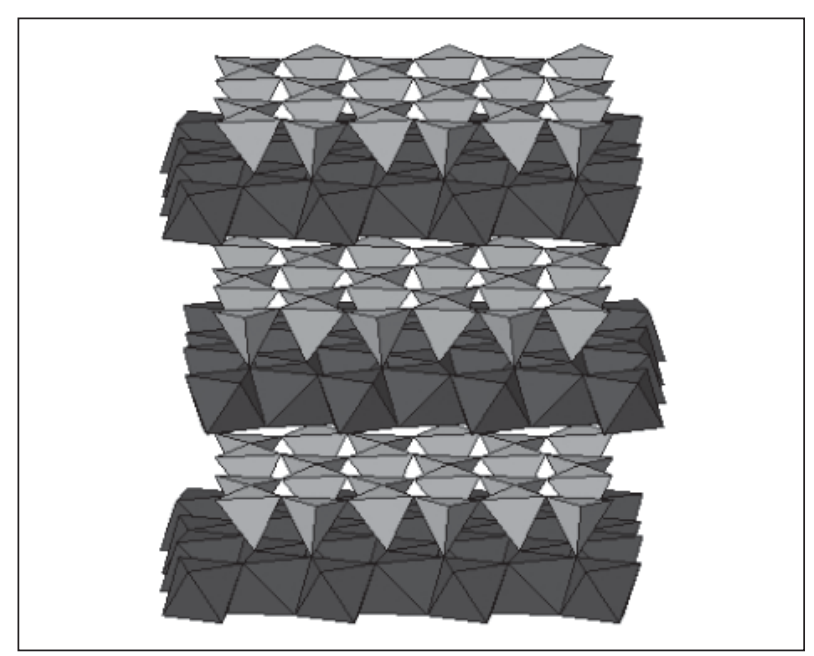

Fig. 4. - The change of the tethaedrical (light) and octaedhrical (dark) sheets

A tetraéderes (világos) és oktaéderes (sötét) lapok váltakozása
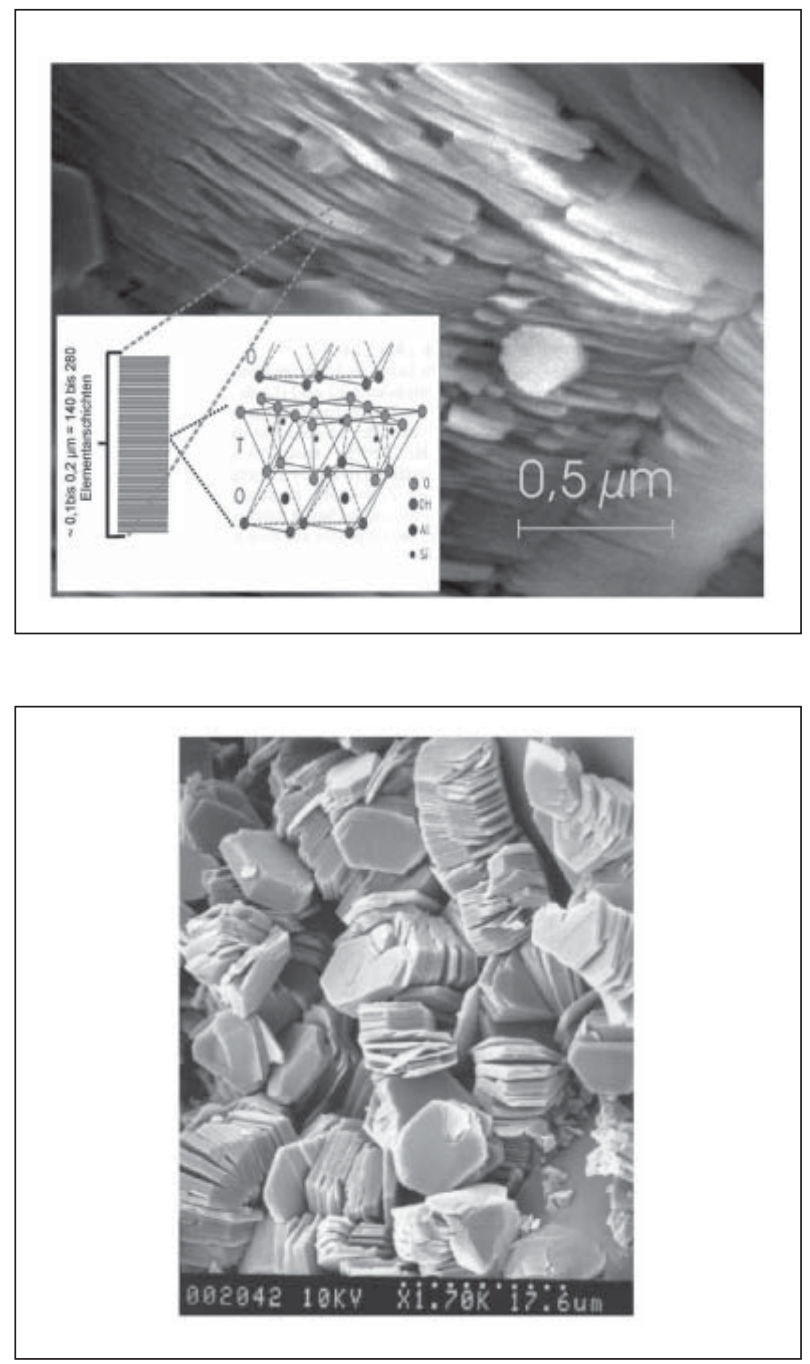

Fig 5. - Kaolinite crystals.

On the right the inset depicts the elementar structure Kaolinit kristályok.

A felsö kép betét-ábrája az elemi szerkezetet mutatja be.
The base shape and the lamellar structure of kaolinite chrystals are clearly shown in Fig. 5. One lamella crystal consists of up to 200 elementar layers $[4,12]$.

Real kaolinite crystals contain defects. The density of defects has a significant effect on the thermal stability of kaolinite. A sample with lower density of defects is more stable, and the dehydroxylation begins at higher temperatures [8].

\section{Structure of metakaolinite}

Dehydroxylation is a reaction of decomposition of kaolinite crystals to a partially disordered structure. This change is followed with a smaller shrinkage of the dimensions of the sample and the porosity rise [3]. The first present of dehydroxylation were identificated by changes of mechanical [13], electrical [14] properties and also by weight loss. The results of isothermal firing show that the dehydroxylation begins at $\sim 420^{\circ} \mathrm{C}$. The chemical equations describing this process is

$$
\mathrm{Al}_{2} \mathrm{O}_{3} \cdot 2 \mathrm{SiO}_{2} \cdot 2 \mathrm{H}_{2} \mathrm{O} \rightarrow \mathrm{Al}_{2} \mathrm{O}_{3} \cdot 2 \mathrm{SiO}_{2}+2 \mathrm{H}_{2} \mathrm{O}(\mathrm{g}) \text {. }
$$

The result of dehydroxylation is a new phase called a metakaolinite. During this reaction, as XRD showed, the higher-order reflections lost their intensity and vanished in the XRD background. This result led to the opinion, that the metakaolinite can be amorphous, now a conception of the short-range order crystalline structure of metakaolinite predominates $[10,15-17]$. The loss of high-order reflections indicates that dehydroxylation results in structural disturbances through the breaking of unstable bonds. As a result, the degree of ordering became lower than that in kaolinite as dehydroxylation progressed. The metakaolinite does not collapse but, rather, retains a layered structure. The first attempt to compile a crystallographic 
model of metakaolinite was made by Brindley and Nakahira $[16,17]$, who proposed ideal well-ordered lattice Fig. 6. Metakaolinite maintains the $\mathrm{a}$ and $\mathrm{b}$ kaolinite lattice parameters, but c-axis parameter disappears, leading to diffuse of the XRD patterns. Octahedral layer is likely to be changed more than the tetrahedral silica layer during dehydroxylation process. Presumably, the remnant oxygen and vacant anion sites rearrange as a way to lower lattice energy. The structure of metakaolinite allows the kaolinite to collapse to $0,63 \mathrm{~nm}$ in agreement with the measured densities of kaolinite and metakaolinite. Proposed structure of the metakaolinite shows no $\mathrm{OH}$ groups. A recent work [10] assumes the rearrangement of the oxygen and vacant sites, which gives stability to the layered structure. This rearrangement builds modulations along the c-axis in metakaolinite with a period of $0,14 \mathrm{~nm}$.

If the metakaolinite has a structure shown in Fig. 6., that means a regular one, that should be displayed by XRD reflection. As it was mentioned above, it is impossible to find the metakaolinite structure by XRD analysis. Consequently, the structure of metakaolinite depictured in Fig. 6 . must be considered as idealized.

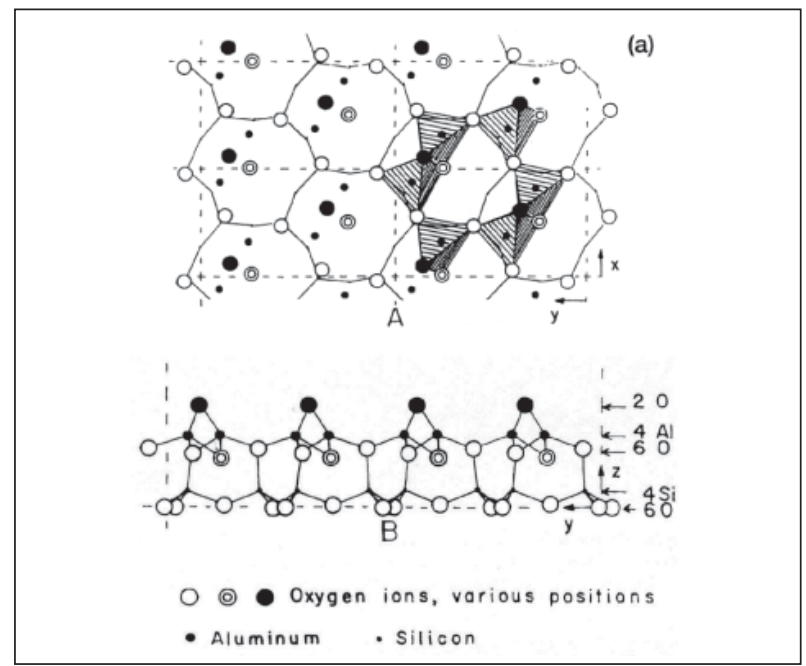

Fig. 6. - Lattice of metakaolinite supposed by Brindley and Nakahira A metakaolinit kristályrácsa Brindley and Nakahira feltételezése szerint

Oxigén ionok különbözö pozíciókban (alumínium, szilícium)

A revisited structural model of metakaolinite was proposed by MacKenzie by computer simulation and nuclear magnetic resonance studies [19]. This structure accounts the presence of $11-12 \%$ residual $\mathrm{OH}$ groups, which are incorporated in the Al-O layers. This structure is shown on Fig. 7. MacKenzie assumes that homogeneous and inhomogeneous mechanisms of the dehydroxylation are possible. Water is lost from the first regions, which became micropores, and the structural continuity is preserved in the second regions, which became metakaolinite. From the model of MacKenzie it could be excepted that the residual $\mathrm{OH}$ groups will liberate at higher temperatures.
The liberation of $11 \%$ of residual $\mathrm{OH}$ groups jointed into water molecules escaping from the sample had to be clearly displayed on TGA curves. For example, our measurement of three English and two Czech kaolins does not prove the two-step dehydroxylation.

A different view on the metakaolinite structure can be found in [20]. About $22 \%$ of the crystal volume is diverted by escaping $\mathrm{H}_{2} \mathrm{O}$ that theoretically decreases the lattice parameter $\mathrm{c}$ from the value $0,713 \mathrm{~nm}$ to $0,556 \mathrm{~nm}$ (parameters $a, b$ remain to be constant). But experimentally it was found $\mathrm{c}=0,685 \mathrm{~nm}$. This disagreement was solved by a new model of the metakaolinite structure with high concentration of the polarized vacancies. That structure is unstable with excess of the lattice energy. This energy is released during exothermic reaction at the temperature $950{ }^{\circ} \mathrm{C}$ when the structure shrinks $\sim 20 \%$ and changes into new phase with different structure.
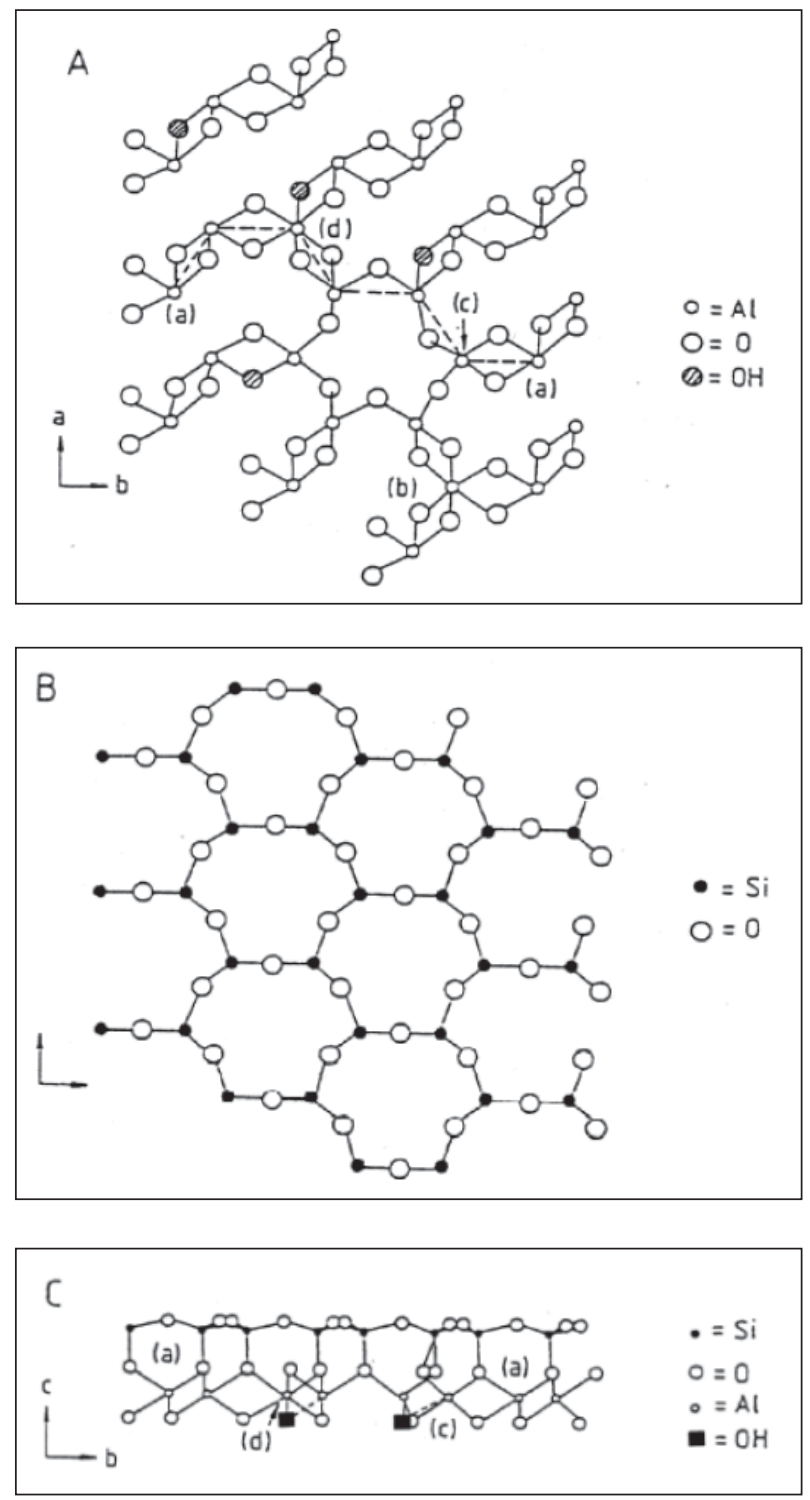

Fig. 7. - Structure by MacKenzie

A metakaolinit szerkezete MacKenzie szerint 


\section{Conclusion}

Nowadays the structure of kaolinite is well known. It is build up by octahedrical layers of $\mathrm{Al}(\mathrm{O}, \mathrm{OH})_{6}$ and tetrahedrical layers of $\mathrm{SiO}_{4}$, which varies in 1:1. The structure of metakaolinite, created from kaolinite at the temperatures higher than $400{ }^{\circ} \mathrm{C}$ is still not clear. This is caused by the absence of XRD reflections, which could show exactly the metakaolinite structure. What is generally known in the present time, it is double layer structure of the metakaolinite taken from the kaolinite crystal. The most commonly spread imagination of the structure of metakaolinite presents a metakaolinite crystal as a crystal with high concentration of defects.

\section{Acknowledgements}

This work was supported by grant VEGA 1/3179/06. The author thanks to Dr. I. Štubňa for his help.

\section{References}

[1] http://www.inchem.org/documents/ehc/ehc/ehc231.htm\#2.2.2

[2] http://www.georgiamining.org/Kaolin/kaolin.htm

[3] Norton, F.H.: Fine ceramics - technology and applications. McGraw-Hill Book Co., New York 1970.

[4] http://www.nanomineral.info/MH_eng.htm

[5] http://www.chemicalland21.com/industrialchem/inorganic/KAOLIN.htm

[6] Štubňa, I. - Varga, G. - Trník, A.: Investigation of kaolinite dehydroxylation is still interesting. Épitöanyag, 58, 2006., N1, p. 6-9
[7] http://europa.eu.int/eur-lex/sk/dd/docs/2001/32001L0030-SK.doc

[8] Čičel, B. - Novák, I. - Horváth, I.: Mineralogy and crystallochemistry of clays. SAV, Bratislava 1981.

[9] http://webmineral.com/data/Kaolinite.shtml

[10] Sujeong Lee - Youn-Joong Kim - Hi-Soo Moon: Energy-filtering electron microscopy (EF-TEM) study of a modulated structure in metakaolinite represented by a $14 \bigcirc$ modulation. J. Amer. Ceram. Soc., 86, 2003., N1, 174-176.

[11] Iqbal, Y. - Lee, W.E.: Microstructural evolution in triaxial porcelain. J. Amer. Ceram. Soc., 83, 2000., N12, 3121-3127.

[12] http://www.arenisca.com/kaolnite.gif

[13] Kozik, T. - Šubřa, I.: Mechanical strength of the ceramic material in the dehydroxylation temperature region. Silikáty, 25, 1981., N3, 237-241.

[14] Kozik, T. et al.: The temperature dependence of the electric conductivity of unfired porcelain mixture. Ceramics-Silikáty, 36, 1992., N2, 69-72.

[15] Chin-Yi Chen - Wei-Hsing Tuan: Evolution of mullite texture on firing tape-cast kaolin bodies. J. Amer. Ceram. Soc., 85, 2002., N5, 1121-1126.

[16] Brindley, G.W. - Nakahira, M.: The kaolinite-mullite reaction series: I, A survay of outstanding problems. J. Amer. Ceram. Soc., 42, 1959., N7, 311-314.

[17] Brindley, G.W. - Nakahira, M.: The kaolinite-mullite reaction series: II, Metakaolin. J. Amer. Ceram. Soc., 42, 1959., N7, 314-318.

[18] Brindley, G.W. - Nakahira, M.: Kinetics of dehydroxylation of kaolinite and halloysite. J. Amer. Ceram. Soc., 40, 1957., N10, 346-350.

[19] MacKenzie, K.J.D.: Feats of clay, or mineral chemistry revisited. Chemistry in New Zealand, 1978., N3, 8-12.

[20] Freund, F.: Kaolinite-metakaolinite, a model of a solid with extremely high lattice defect concentration. Ber. Deutsche Keram. Ges., 44, 1967., N4, 5-13. 